
\title{
R Reserach S Suare \\ Identification of microbial signatures of oilseed rape yield decline at the landscape scale
}

Sally Hilton

Emma Picot

Susanne Schreiter

David Bass

Keith Norman

Anna E. Oliver

Jonathan D. Moore

Tim H. Mauchline

Peter R. Mills

Graham. R. Teakle

lan. M. Clark

Penny. R. Hirsch

Christopher. J. van der Gast

Gary. D. Bending

Video Byte

Keywords: Oilseed rape, Microbiome, Rhizosphere, Roots, Landscape, Yield decline, Brassicaceae, canola, agronomy, agriculture

Posted Date: February 25th, 2021

DOI: https://doi.org/10.21203/rs.3.rs-276067/v1

License: (c) (i) This work is licensed under a Creative Commons Attribution 4.0 International License.

Read Full License 


\section{Abstract}

With the world's population expected to grow to over 9 billion by 2050, food is a major concern. Much of our increased food needs could be met by improving the yield of agricultural crops. A recent study examined one aspect of plant health: the plant microbiome, which plays a critical role in host health and productivity. Researchers focused on oilseed rape (OSR), the third most cultivated crop in the UK and a major source of vegetable oil. Field experiments have indicated that OSR yield declines proportionally with how often it is grown in rotation and while this has been associated with changes to the rhizosphere microbiome, it is unknown which microbes negatively affect plant yield. Comparing rhizosphere soil and bulk soil samples from 37 farms across the UK, they found that protists, bacteria, and fungi were influenced differently. Fungi were more widely influenced by the rotation frequency, but specific bacteria and protist species were also affected. Interaction networks identified key and novel microbes which could be indicators of crop health. Overall, these results suggest that at the landscape scale, OSR crop yield is governed by complex communities of both pathogens and beneficial biota. The signatures of microbial dysbiosis identified in the study may help develop strategies to improve crop yield. 